\title{
Literary Symbols as the Creative and Original Impulses of Literary Creation ${ }^{1}$
}

\author{
ANNELI MIHKELEV
}

\begin{abstract}
Literary symbols contain something archaic, sometimes going back to pre-literate times, and every new context gives to these symbols a new meaning. The poetical text segment carries with it its old context from the older or archaic text and, if it is situated in a new context, the new context also adds new meaning to the symbol. The archaic aspect and a new textual context combine in the literary symbols; it comes from the past and passes on into the future. That is the most important idea in terms of the essence and the dynamics of the literary symbol. This paper analyses the well-known literary figure Hamlet, how Hamlet has become a literary symbol, and how it works as a literary symbol in unexpected cultural relationships. There are very different performances and interpretations throughout the world, but thanks to the archaic aspect we still recognize the old story of Hamlet. The paper concentrates on the examples of Hamlet as a literary or cultural symbol in various cultural and literary texts from Estonian culture. For example, Hamlet as a symbol of new life in Gustav Suits's poetry or Hamlet as a symbol of the resistance movement in Paul-Eerik Rummo's poetry, Estonian theatre and choral music. There are several religious myths and symbols embedded in Suits's poem "Hamleti proloog" ("The Prologue of Hamlet”, 1913). Suits's poem "Oma saar" ("My Island") is a literary text which represents the possibility that whole the poem may be a symbol (cf. William Blake's poem "Sick Rose"). A symbol works in culture as a place where the fundamentally new is created, and it is a process which contains the moment of explosion, as we see in different cultures, including in the Estonian culture's use of the literary symbol Hamlet or an island. All these symbols are dynamic and it depends on the context and on readers how these literary figures and texts are interpreted.
\end{abstract}

Keywords: literary symbols; Estonian literature; mythology; symbolism; Hamlet

1 This study was supported by the Estonian Ministry of Education and Research (IUT18-4) and the Centre of Excellence in Estonian Studies (project No TAU16078).

DOI: https://doi.org/10.12697/IL.2018.23.2.12 
The question of the essence of literary figures as symbols, metaphors and myths has always been complicated and problematic. Such figures are dynamic phenomena and sometimes it is difficult to understand what a figure represents in a text. A Dictionary of Literary Terms defines a symbol as "something which represents something else (often an idea or quality) by analogy or association (white, lion, rose etc.). Such symbols exist by convention and tradition" (Gray 1992: 282), and it is obvious that most literary figures, including metaphors and myths, and poetic language in general, represent something else than direct meaning. It seems that all these figures are dynamic and it depends on the context and on readers how these literary figures and texts are interpreted. The author, the text and the reader are the three components which make up the literary dialogue in Mikhail Bakhtin's work. All the components of the dialogue work together and constitute the meaning of the text, and every component has its own function in the dialogical process. The interaction between all three components is dynamic and the meaning of the literary text is created in the process of communication. Literary dialogue and communication also maintain distance, both spatial and temporal, between the author and the reader: the author and the reader do not stay in the same room and usually they do not have contact with each other, because the literary communicative process is mediated through the literary text, which is written beforehand. In other words, the author and the reader have no physical contact in the literary dialogue; the communication takes place through the text. This means that, first, dialogue takes place between the author and the text, or between the creator and the creator's object. The third component, the reader comes into play a bit, sometimes much later. The distances, both spatial and temporal, are different, varying from reader to reader. It is possible that there is only one author, whereas many readers communicate through the text. In terms of the three components of the literary dialogue, the central one is still the text, which is created by the author and interpreted by the reader. Juri Lotman refers to the text as a personified phenomenon, which has its own very important, and at the same time very specific function(s) in the literary communicative process. There are three textual functions according to Lotman: the creative function, the text memory, while the text is not only the generator of new meaning, but also a condenser of cultural memory, and the last function is connected with the social-communicative process. (Lotman 2000: 63-81)

According to Mikhail Bakhtin, every communicative process includes not only direct verbal signs, but every communicative process, every dialogue, also includes all the discourses or (social) contexts with their different sign systems and they exist around the utterance or the text; not only verbal signs take part in the dialogue, but also different sign systems. And the author and the reader 
are usually involved in different discourses. That fact also influences the text, which consists of verbal signs: the text is surrounded by different sign systems in discourse (Bahtin 1987: 212-234).

The text itself usually contains only verbal signs (though sometimes it may contain other kinds, for example, visual signs), but the discourse surrounding the text contain different sign systems: verbal, visual and aural. The written text may indicate or allude to different worlds around itself: fictional worlds (verbal or visual signs) or illustrations and pictures (visual signs), other literary texts (verbal signs), mass-media (a combination of different sign systems), etc. Different sign systems are always mixed in the process of writing and interpretation.

Literary symbols contain something archaic which sometimes go back to pre-literate times and every new context gives to these symbols a new meaning. There are several well-known and very old literary symbols which contain something archaic, but they have been different meanings in different times (Pygmalion, Hamlet, Odysseus, rose etc). These literary symbols belong to the active canon of world literature and national literatures. A poetical text segment carries with it its old context from the older or archaic text and, if it is situated in a new context, the new context also adds new meaning to the symbol as we see sometimes in small and peripheral cultures. Literary symbol is a dynamic phenomenon and cultural transfer and intertextuality play a significant role when the symbol enters a new textual context with the new meaning and it may become also the new symbol.

At the same time, conventions and traditions are still very important, because "writers use these conventional symbols but also they invent and create their own" (Gray 1992: 282). The author has his/ her own intentions, which live in his/ her text. We can say that the author's intentions depend on the reader's competence and capacity to understand them. The most important role of the reader is to discern and recognize those intentions. The reader constitutes meaning according to the text created by the author, and the dialogue requires a balance between author, text and reader.

It is also possible that symbols, metaphors and myths are very close, especially from a diachronic viewpoint (see Wellek, Warren 2010: 260-301). A symbol may be seen as a species of metaphor in which the exact subject of the metaphor is not made explicit: the relation between the text segments carries with it the context from an older or archaic text and, if it is situated in a new context, the new context also adds new meaning to the symbol. If the exact subject of the metaphor is not made explicit, it may be mysterious. A whole poem may be a symbol of this kind, such as William Blake's "Sick Rose" (ibid.). 
MIHKELEV

William Butler Yeats used Irish mythology and folklore in his works (e.g. The Stolen Child, 1889; The Man Who Dreamed of Faeryland, 1893; The Hosting of the Sidhe, 1899). His poems are passionate and full of contrasts (e.g. The Lover Tells of the Rose in his Heart, 1899). The red rose is a symbol of freedom which occurs again and again in Yeats' poems, for example The Rose Tree (1921) where the dialogue between two Irish freedom fighters is:

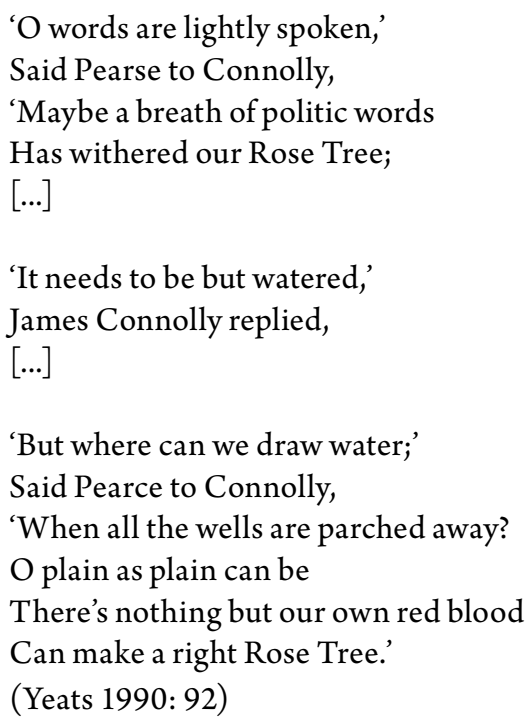

The Estonian poet Gustav Suits was especially influenced by the French symbolists, and also Finnish and Russian writers. At the beginning of the $20^{\text {th }}$ century, the poetry of Gustav Suits was revolutionary and romantic, with pathos and optimism:

His first collection, The Fire of Life (Elu tuli, 1905) is the simplest of all his poetry books, the most popular, reader-friendly and appealing, due to its youthful enthusiasm. It was a kind of preparation for the readers of that time for more demanding lyrical works. The manner of the young poet betrays the influences of Friedrich Nietzsche and the Finnish poet Eino Leino, but it also reveals traces of 19th century Estonian national romanticism. (Süvalep 2003: 18)

His poem "Oma saar" ("My Island", 1905) from the first collection Elu tuli (The Fire of Life) is written in a symbolist style: 
Literary Symbols as the Creative and Original Impulses of Literary Creation

Still I keep sailing and sailing,

And seeking an isle in the sea:

I have sought it long already

Where the random winds sail free.

The sea has many islands

And havens expectant with light,

But I cannot find the island

I dreamed in the dazzled night.

And still my vessel keeps scudding

On a swaying circular plain,

And the clouds above me go swaying,

And I seek my island in vain.

(Suits 1953: 31, trans. by W. K. Matthews)

It seems that whole the poem by Suits may be a symbol: the island may be his homeland, his own land in the context of the revolution of 1905; it may represent also the spirit of the poet's soul or something universally human or typical of $20^{\text {th }}$ century man with doubts, disappointment in rationalism, feelings of insecurity. And finally, the island may be also a utopia as an ideal place or state of life and it is also a very old cultural symbol which contains something archaic and each new context gives the symbol a new meaning.

Anne Lange has written: "Symbolism in its Western form, intellectually searching, with much emphasis on a highly individual, sophisticated style, characterises the verse of Gustav Suits, the real creator of modern Estonian poetry..." (Lange 2002: 24).

\section{Hamlet as a literary symbol}

I would like to illustrate my ideas with the well-known literary character Hamlet. It has been asked how Hamlet has become a literary symbol. I think Shakespeare's play and its main protagonist provide useful material, because it is a very heterogeneous text and sometimes researchers speak of Hamlet as a literary myth or metaphor.

Hamlet's story is a very old and well-known and it has several variants:

If we are looking for parallels at the level of the main narrative and structure of the play, there are plenty of stories about sons who avenge the deaths of their fathers. They include the Persian legend of Kei Chosra [...] And ancient Greece provides the stories of Orestes. [...] But there is also an old Nordic story of a 
MIHKELEV

clever son whose name Amoldi or Amleth [...] also means 'stupid'. It was written down in Latin about AD 1200 by Saxo Grammaticus, as part of the collection of tales which were printed in Paris in 1514 as Danorum Regum heroumque Historiae. (Thompson, Taylor 2006: 63-66)

Most probably Shakespeare read these tales in a popular collection. Thus, Hamlet as a cultural symbol existed before Shakespeare's text. Juri Lotman has written: "a symbol exists before any given text and independently of it. It surfaces in a writer's memory from the depths of cultural memory and comes to life in a new text like grain in fresh soil." (Lotman 1990: 105) Hamlet as a literary symbol contains an archaic aspect which is recognizable in different contexts and the story was adapted from an old chronicle. Actually, Shakespeare changed the story or legend by Saxo and he created his own story of Hamlet, with a main protagonist who became more and more popular in different countries and in different contexts.

Hamlet as a symbol functions in culture as an example of Lotman's statement:

a symbol being a finalized text, does not have to be included in a syntagmatic chain; and if it is included in one, it preserves its own semantic and structural independence. [...] This leads us to another important feature: a symbol never belongs only to one synchronic section of a culture; it always cuts across that section vertically, coming from the past and passing on into the future. A symbol's memory is always more ancient that the memory of its non-symbolic textcontext. (Lotman 1990: 103)

The text of Hamlet has existed for hundreds of years, not only in European culture but in world literature:

... symbols are important mechanisms of cultural memory; they can transfer texts, plot outlines and other semiotic formations from one level of a culture's memory to another. [...] A symbol stands out as something different from the textual space that surrounds it, like an emissary from other cultural epochs (or from other cultures), a reminder of the ancient (or eternal) foundations of that culture. On the other hand, a symbol actively correlates with its cultural context, transforms it and is transformed by it. Its invariance is realized in variants. (Lotman 1990: 104) 
According to Lotman, the most important aspect is that the semantic potentials of the symbol are always greater than any realisation of them: the links which, with the help of its expression, a symbol establishes with a particular semiotic context never exhaust all of its semantic valence. "This is the semantic reserve thanks to which a symbol can enter into unexpected relationships, altering its essence and deforming its textual context in unpredictable ways." (Lotman 1990: 104)

If we think about Hamlet as a literary symbol, it works in the same way: as a symbol it enters into unexpected cultural relationships, it is popular in unexpected countries (e.g. in Japan and China) and there are very different performances and interpretations throughout the world, but thanks to the archaic aspect we still recognize the old story of Hamlet.

Sigmund Freud has written after he sketched his theory of the Oedipus complex that in Hamlet Shakespeare's unconscious understood the unconscious of his hero in this way. "More than any other of Shakespeare's plays, Hamlet has attracted psychoanalytic critics, and Hamlet and Ophelia have become respectively the iconic representatives of male and female instability." (Thompson, Taylor 2006: 26)

According to Lotman, the symbol contains an iconic element which connects the expression level and content level, so that the "[c] ontent merely glimmers through the expression, and the expression merely hints at the content. [...] A symbol, then, is a kind of condenser of all the principles of sign-ness... [...] It is a mediator between different spheres of semiosis, and also between semiotic and non-semiotic reality. In equal measure it is a mediator between the synchrony of the text and the culture's memory. Its role is that of a semiotic condenser." (Lotman 1990: 111)

Since a symbol always contains something archaic and it transfers an old text diachronically to a new context, we can say that a symbol is a phenomenon which creates something new. According to Lotman, "In the phenomenon of art it is possible to isolate two opposing tendencies: the tendency toward the reception of that which is already known and the tendency toward the creation of that which is fundamentally new" (Lotman 2009: 154).

I think that a symbol works in culture as a place where the fundamentally new is created, and it is a process which contains a moment of explosion: "The state of explosion is characterized by the moment of equalisation of all oppositions. That which is different appears to be the same. [...] The impossible becomes possible. This moment is experienced outside of time, even if, in reality, it stretches across a very wide temporal space." (Lotman 2009: 158) 
MIHKELEV

\section{Hamlet as a symbol of new life}

Very good examples of Hamlet as a literary or cultural symbol exist in various cultural and literary texts from Estonian culture. The first Shakespeare play on the Estonian stage was The Merchant of Venice on the $24^{\text {th }}$ of January in 1888 by semi-professional theatre Vanemuine in Tartu. The next Shakespeare play on the same stage was the comedy The Taming of the Shrew in 1889. The next step towards more professional production was taken by the theatre Estonia in Tallinn, which had begun working as a professional theatre in 1906. In 1910-1913 Shakespeare's tragedies Othello (1910), King Lear (1911) and Hamlet (1913) were presented in the same theatre. There was an assembly of particularly talented and legendary actors of the time in the theatre Estonia, and the greatest success of the cast of the Estonia Theatre was the production of Hamlet. It was presented at the inauguration of the impressive new building, with its large stage and spacious hall, and the text of the tragedy was translated from the original language (both Othello and King Lear had been translated from German). So, the first Estonian translation of Hamlet (translated by Aleksander Ferdinand Tombach in 1910) was the introduction of Shakespeare in the Estonian language. In a cultural sense that was indeed rather late, but there were several complicated political and historical factors which had dominated in Estonia till the beginning of the $20^{\text {th }}$ century. The actors Theodor Altermann and Erna Villmer, who played Hamlet and Ophelia, had attained great mastery by that time, and Shakespeare was one of the most popular playwrights in Estonia (Kask 1964: 263-265).

Gustav Suits wrote poem series Hamleti proloog (The Prologue of Hamlet, 1913), which was published first in the newspaper Tallinna Teataja and then in Suits's collection Kõik on kokku unenägu (All is But a Dream, 1922). Hamleti proloog was written to celebrate a very important event in Estonian culture. On 24 August 1913 the Estonia Theatre's new building opened in Tallinn. It was a drama theatre, and later became an opera house. It was a very important day for Estonians. Hamlet, the Danish prince, became a historical symbol as a man who fought during a complicated and hostile time (see Oras 2003: 20-21). Hamleti proloog contains seven poems, and each poem has its own unique structure, but all of the strophes contain three lines, echoing Dante's terza rima from the Divina Commedia (1472). Suits used two "external" texts to describe and interpret Estonian culture. He put an old motif or symbol into an unexpected and new context and created a new symbol that was significant to the Estonian public. Although the archaic aspect of Hamlet is well-known, in the new Estonian context the new additional meaning exists in the synchronic section of a culture (Estonian culture), and the symbol of Hamlet came from 
Literary Symbols as the Creative and Original Impulses of Literary Creation

the past and passed into the future, which became apparent in later Estonian culture.

But more than the form of terza rima connects Suits's prologue with Dante's Divine Comedy; the content of the prologue is similar to Dante's work: the poem series is like a journey (it is also a literary symbol) through Estonian history and landscapes, and images of reality alternate with images of fantasy and dream motifs. Suits's seven poems form a parallel with symbol purgatory in Dante's work and in religious texts. There are several religious myths and symbols embedded in Suits's poem. In the fifth poem, Suits presents the ghost of the great William Shakespeare, who finally has arrived in Estonian theatre and culture, and the protagonist Prince Hamlet is the symbol of that time.

\section{Hamlet as a symbol of the resistance movement}

The most influential part of the play Hamlet is the famous monologue of Prince Hamlet:

To be or not to be, that is the question;

Whether 'tis nobler in the mind to suffer

The slings and arrows of outrageous fortune

Or to take arms against a sea of troubles

And by opposing end them? To die: to sleep;

(Shakespeare 2006: 284-285)

Hamlet's monologue expresses a complicated situation, in which there is no good solution, and the protagonist thinks about what to do, to be a rebel or to be a conformist, and this is an existential question for him.

Douglas Bruster writes: "By to be, Hamlet could mean (among other things) 'to live' or 'to exist', with not to be thus implying 'to die' or to 'cease to exist'. It is important to note that the division here - being and not being - was one of the stable alternatives in philosophy at the time. Doctor Faustus, the cerebral title of Christopher Marlowe's great tragedy (written about a decade before Hamlet), actually takes up this question in its Greek form - on kai me on ('being and not being' - pronounced 'own kai may own'). Faustus attributes this issue to Aristotle, and discards it as not pragmatic enough for his tastes. In this philosophical register, To be, or not to be provides a mutually incompatible contradiction; things have to be one way or the other: either they exist or they do not. A contemporary form of Hamlet's proposition in Latin reads est aut non est: that is, the question of whether something 'is or is not."' (Bruster 2007: 17)

Hamlet's existential question has inspired several Estonian poets and writers, as existentialism. According to Rein Veidemann, "In the $20^{\text {th }}$ century, 
MIHKELEV

many writers have influenced the development of existentialist philosophy and they in turn had an influence on the Estonian literature in the 1950s and 1960s. [...] Existentialism found an especially strong resonance in the Estonian literature in the second half of the 1960s. It was promoted by the absurdity of the whole Soviet life..." (Veidemann 2000: 50), and that was illustrated by several literary works. This literary rebellion in Estonian literature in the 1960s had a political character; it fused with several local tendencies and ideas from Western Europe, although the particular ideas were translated into the local cultural system and adapted to local conditions. And it is interesting and paradoxical that Estonian existentialism was more influenced by Camus' ideas than by Sartre's, because in the western European tradition Camus is considered to be less political than Sartre.

Gustav Suits is not the only poet to use the motif of Hamlet in his works. Paul-Eerik Rummo was one of the major authors of the Estonian poetry innovation of the 1960s. His poem Hamleti laulud (Hamlet's Songs) was published in 1964 in his second collection of poetry, Tule ikka mu rõomude juurde (Always Come to My Joys). More serious aspects, together with a sense of danger and the realisation of life's fragility, are present in Rummo's second collection, especially in the poem Hamlet's Songs (see Olesk 2001: 444).

The first strophe of the Rummo's poem Hamlet's Songs establishes a dangerous and threatening atmosphere: something is ominous, and nature creates a tangible feeling of fear. The cutting grass and a child who has injured his hand on the cutting grass represent that situation; it is an inexplicable feeling. The atmosphere is quite similar to the atmosphere of Shakespeare's play:

The sea withdraws into itself. It is ebb tide.

On the dunes a steak of storm-foam fades.

Listen: what is the breeze rustling,

Ominous and lurking?

Saw grass, oh friend saw grass.

And gathering before us a cloud-mass.

(Rummo 2006: 8, trans. by Jüri Talvet and H. L. Hix)

The next lines of the poem introduce an unexpected contrast:

a couple of lovers who run, fearless,

along the beach, barefooted,

barefooted and in their veins the windwine - - -

(Ibid.) 
Literary Symbols as the Creative and Original Impulses of Literary Creation

The lovers express positive and optimistic emotions in the poem; they do not fear the stormy sea and cutting grass, although these are dangerous:

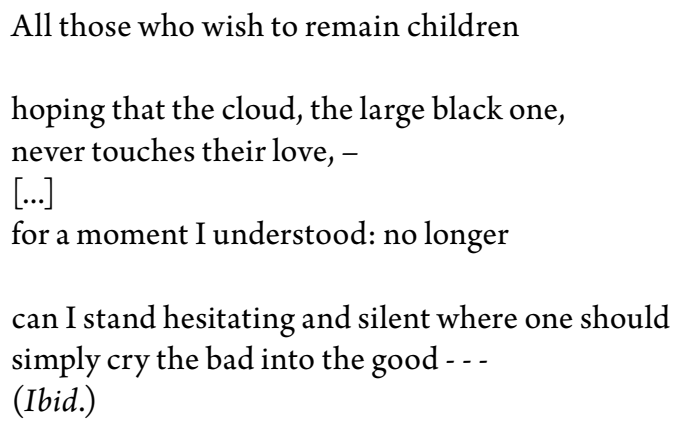

The second part of the song sounds like an answer to Shakespeare's protagonist Hamlet:

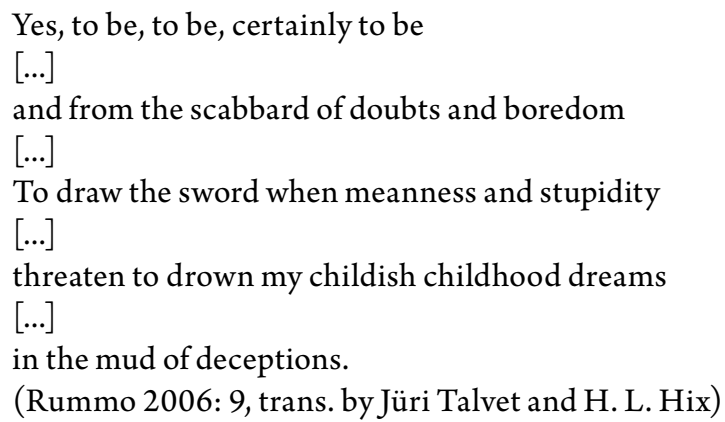

Between these lines above the lines in italics and brackets repeat as a refrain:
(Ah, only one lap, only one lap on which to rest my head!) (Ibid.)

Most probably the refrain alludes to the contradictory and tense dialogue between Hamlet and Ophelia in the second scene in the third act of Shakespeare's play:

HAMLET Lady, shall I lie in you lap?

OPHELIA No, my lord.

HAMLET Do you think I meant country matters?

OPHELIA I think nothing, my lord.

(Shakespeare 2006: 304-305) 
MIHKELEV

Although there is a dialogue between Rummo's and Shakespeare's texts, the meanings of Rummo's and Shakespeare's texts are opposites. Rummo's text was written at the beginning of the 1960s in the Soviet Estonia, it sounds like a beat poem from USA or Western Europe in the mid-1950s to 1960s. The last strophe intensifies the idea of anti-violence or anti-war:

Thus to be, and at the same time to know

that life is not our struggle, to know

that what is coming is greater than me

and also greater than my enemy. Thus to be, and at the same time

to think of the children yet unborn whose laughter

destroys the swords of both of us.

(Rummo 2006: 9-10, trans. by Jüri Talvet and H. L. Hix)

It seems the main idea of this poem is "Make love not war!" or, as Frank Sinatra sang and alluded to the monologue of Hamlet in the song Let's Fall In Love, in 1960: "to be or not to be, let our hearts discover". Rummo's poem was a new approach to the topic of anti-war in the Soviet context, because the idea of love and children express the main idea of the poem. Rummo brought more humanity and bright feelings to the poetry of Soviet Estonia, and that poem expresses also the influences from the Western Europe culture.

The historical and political situation in Estonia was, for many centuries, very similar to that in Shakespeare's play Hamlet, represented in the First Folio's phrase about Denmark being a prison. The dialogue between Hamlet and his friends Guildenstern and Rosencrantz before the players give the performance is very significant. Rosencrantz says to Hamlet:

... the world's grown honest.

HAMLET Then is doomsday near - but your news is not true. But, in the beaten way of friendship, what make you at Elsinore?

(Shakespeare 2006: 254-255)

Folio-only passages of Hamlet contain the famous lines about Denmark and prison which explains the word "true":

HAMLET ... Let me question more in particular. What have you, my good friends, deserved at the hands of Fortune that she sends you to prison hither?

GUILDENSTERNE Prison, my lord?

HAMLET Denmark's a prison.

ROSINCRANCE. Then is the world one.

(Shakespeare 2006: 466) 
This dialogue, especially the Folio-only passage characterises a totalitarian society, such as the Soviet Union, Soviet Estonia and other Eastern European countries or the Russian Empire (see Thompson, Taylor 2006: 115-122; Shakespeare 2006: 466). One of the best examples of Hamlet as a symbol of political resistance is Boris Pasternak's (1890-1960) banned novel Doctor Zhivago (1957). Pasternak's novel ends with the poem Hamlet where the poetic 'ego' of Pasternak identifies with Hamlet's and Christ's destiny and mission (see Pärli 1999: 558).

The Estonian prose writer Jaan Kross' (1920-2007) novel The Czar's Madman (1978) contains implicit play with the motif of Hamlet: the protagonist of the novel 'Timotheus von Bock is declared mad for criticising the Czarist regime, a fate which also befell dissidents in the Soviet times" (Kronberg 2005: 68). Kross does not use direct reference to Shakespeare's play Hamlet, but there are similar conflict and motives of madness and / or non-madness or pseudo-madness in both literary works. Mardi Valgemäe indicates that Kross plays with Soviet censorship: it seems the plot of the novel The Czar's Madman is about Russian Empire in the $19^{\text {th }}$ century, but actually it is the connotation and the $19^{\text {th }}$ century Russian Empire means $20^{\text {th }}$ century Soviet regime. The protagonist Jakob in the same novel used the similar scheme in his diary: if he writes about Russian romantic poet Zhukovsky he actually concentrates on the life of Timotheus von Bock (Valgemäe 2005: 74). It means that Vassili Zhukovsky means Timotheus von Bock in Jakob's diary and $19^{\text {th }}$ century Russian Empire means totalitarian Soviet regime in the $20^{\text {th }}$ century. Kross' novel is a perfect political allegory which uses also the motif of Hamlet to indicate to the madness or to the schizophrenic situation which may lead to madness.

There are several theatre performances about Hamlet as a political rebel in various eastern European countries (see Thompson, Taylor 2006: 115-122).

Hamlet's existential question receives a certain and vital answer, and that answer brings a new meaning to an existential paradigm which had a strong influence in Estonian culture in the 1960s (see Veidemann 2000: 50; Mihkelev 2013: 86-90).

This poem was innovative in Estonian literature and was used in choral music at the beginning of the 1960s. It formed a prologue to the innovations in Estonian theatre in the second half of the 1960s. Paul-Eerik Rummo's play Cinderella game (Tuhkatriinumäng, 1969), which alludes to Prince Hamlet, is one of the significant plays in the development of Estonian drama (see Kruuspere 2006). Luule Epner has pointed out the key-words of the change in Estonian drama in the 1960s: play, myths, especially literary myths, and ritual. 
The most important mythical and symbolic figures were Antigone and Hamlet, with Hamlet being the more significant. And it is important that Hamlet as a myth existed as the bunch of different meanings or multiple meanings, it did not have only one meaning (Epner 1998: 170-176). There are several authors who used the motif of Hamlet in their literary works and theatre performances, eg Jaan Kaplinski, Mikk Mikiver, Juhan Viiding etc (see Kruuspere 2006).

Consequently, Hamlet as a literary figure has been a very important and influential motif in Estonian literature and culture, and Rummo's text forms the axis around which revolve not only written texts but also such cultural aspects as theatre performance and music. Suits's poem is an Estonian poem about Estonian culture, but both Dante and Shakespeare help him to talk about Estonian culture; their literary works act as meta-texts, but at the same time Suits creates several new symbols and new unexpected meanings in his text.

\section{Conclusion}

A literary symbol is a dynamic phenomenon and a cultural transfer, and intertextuality plays a significant role when a symbol enters a new textual context with a new meaning. Well-known literary character Hamlet becomes a literary symbol or myth which has different meanings in different literary texts and culture: it has multiple meanings not only one. At the same time the literary dialogue between the author, the reader and the text is needed. All the components of the dialogue work together and constitute the meaning of the text. The reader interprets the text and communicates with the author through the text. It makes possible the dynamic processes of literary creation. Hamlet as a cultural symbol may convey also political messages against the totalitarian regimes. Existential question of Hamlet has inspired several Estonian poets and artists and it makes possible many interesting and intriguing performances. Hamlet as a literary symbol represents the idea of freedom and rebellion or adaptation in Estonian poetry. The literary symbol also contains something archaic, stretching back to pre-literate times and each new context gives the symbol a new meaning like in Paul-Eerik Rummo's poetry. A symbol works in culture as a place where the fundamentally new is created, and it is a process which contains the moment of explosion (many new meanings of a well-known cultural object), as we see in different cultures, including in the Estonian culture's use of the literary symbol Hamlet or an island. 
Literary Symbols as the Creative and Original Impulses of Literary Creation

\author{
Anneli Mihkelev \\ anneli.mihkelev@tlu.ee \\ Tallinna Ülikool \\ Humanitaarteaduste instituut \\ Narva mnt 29 \\ 10120 Tallinn \\ EESTI / ESTONIA
}

\title{
References
}

Bahtin, M. 1987. Valitud töid. Trans. M. Jõgi. Tallinn: Eesti Raamat.

Bruster, D. 2007. To Be Or Not To Be. London, New York: Continuum.

Camus, A. 1991. The Rebel. An Essay on Man in Revolt. New York, Toronto: Random House.

Epner, L. 1998. Kahe "Libahundi” vahel ehk Antigone ja Hamlet. - M. Laak, ed., Traditsioon ja pluralism. Tallinn: Tuum, 169-184.

Gray, M. 1992. A Dictionary of Literary Terms. London: Longman York Press.

Kronberg, J. 2005. Jaan Kross. - A Sharp Cut. Contemporary Estonian Literature. Tallinn: Estonian Literature Information Centre, 68.

Kruuspere, P. 2006. Is It Ghosting? The Motifs and Allusions of Hamlet in Estonian Drama. - C. Hasselblatt, ed., Different Inputs - Some Output? Autonomy and Dependence of the Arts Under Different Social-Economic Conditions: The Estonian Example. Maastricht: Shaker Publishing BV, 35-47.

Lange, A. 2002. Six Estonian Poets in Translations of Ants Oras. Kuus Eesti luuletajat Ants Orase tõlkes. Tallinn: Tänapäev.

Lotman, Y. 1990. Universe of the Mind. A Semiotic Theory of Culture. Trans. Ann Shukmann. Bloomington and Indianapolis: Indiana University Press.

Lotman Y.M. 2000. Universe of the Mind: A Semiotic Theory of Culture. Trans. A. Shukman. Bloomington, IN: Indiana University Press.

Lotman, Y. 2009. Culture and Explosion. Trans. W. Clark. Berlin, New York: Mouton de Gruyter.

Mihkelev, A. 2013. Paul-Eerik Rummo "Hamleti laulud" uusi tähendusi loomas. - Acta Semiotica Estica X. Tartu: Eesti Semiootika Selts, 79-99.

Olesk, S. 2001. Paul-Eerik Rummo. - E. Annus et al. Eesti kirjanduslugu. Tallinn: Koolibri, 444.

Oras, A. 2003. Luulekool I. Tartu: Ilmamaa.

Pärli, Ü. 1999. Boriss Pasternak ja „Doktor Živago”. - B. Pasternak, Doktor Živago. Tallinn: Eesti Raamat, 551-558.

Rummo, P.-E. 2006. Hamlet's Songs. Trans. J. Talvet, H. L. Hix. - H. L. Hix, ed., On the Way Home. An Anthology of Contemporary Estonian Poetry. New Delhi: Sarup \& Sons, $8-10$. 
MIHKELEV

Shakespeare, W. 2006. Hamlet, ed. by A. Thompson, N. Taylor. London: Arden Shakespeare.

Suits, G. 1953. Flames on the Wind. Trans. W. K. Matthews. London: Boreas.

Süvalep, E. 2003. Gustav Suits. - Estonian Literary Magazine, 16, 16-21.

Thompson, A., Taylor, N. 2006. Introduction. - W. Shakespeare, Hamlet, ed. by A. Thompson, N. Taylor. London: Arden Shakespeare, 1-137.

Veidemann, R. 2000. Eksistentsialistliku paradigma avaldusi 1950.- 60. aastate eesti kirjanduses. - L. Epner, P. Lilja, eds., Taasleitud aeg. Eesti ja soome kirjanduse muutumine 1950.-1960. aastatel. Kadonneen ajan arvoitus. Viron ja Suomen kirjallisuuden muuttuminen 1950.- ja 1960-luvulla. Tartu Ülikooli eesti kirjanduse oppetooli toimetised 2. Tartu: Tartu Ülikool, 41-50.

Wellek, R.; Warren, A. 2010. Kirjandusteooria. Trans. U. Tõnisson, E.-R. Soovik, K. Ligi. Tartu: Ilmamaa.

Yeats, W. B. 1990. Luulet. Trans. M. Väljataga Tallinn: Eesti Raamat. 